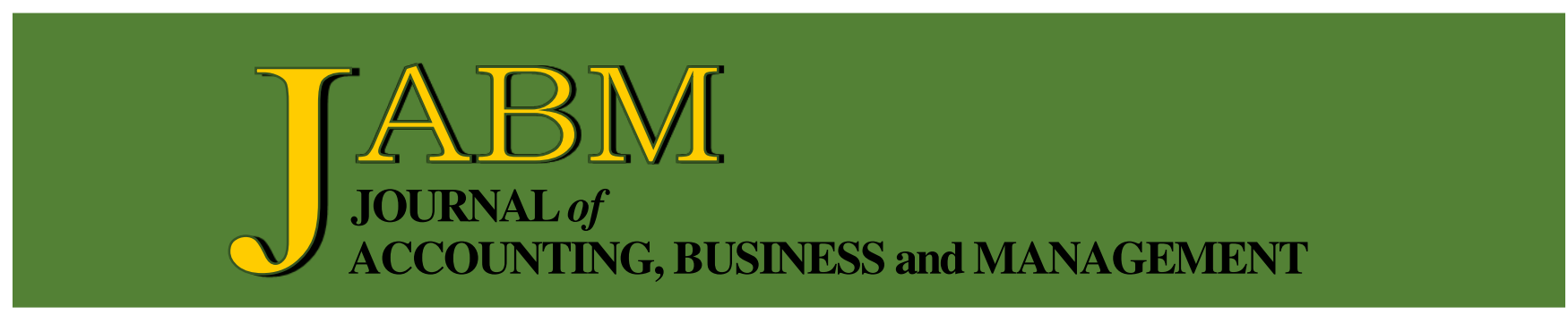

Life Insurance Companies: Determinants of Cost Efficiency and Profitability

Joseph Kwadwo Tuffour, Kenneth Ofori-Boateng, Williams Ohemeng, and Jane Kabukuor Akuaku

Subprime Crisis - A Corporate Acquisition Opportunity?

Vishal Srivastava, Sunder Ram Korivi, and Dipasha Sharma

Consequences of Weak Internal Controls Over Financial Reporting: Foreign versus U.S. Firms

Kathleen Bakarich and Devon Baranek

Impact of Organizational Commitment on Accounting Professionals' Performance: Case of Accounting Firms

Lassaad Abdelmoula and Sami Boudabbous

The Objectives of Sharia Management Accounting Information Reporting: Identification of Values and Characteristics

Sonhaji, Abdul Kadir Usri, and Hedher Tuakia

The Impact of Customer's Perception of the Practices of Corporate Social Responsibility on Purchase Intention

Doaa Abd El Samea and Ahmed Rashed

Corporate Financial Distress: The Impact of Profitability, Liquidity, Asset Productivity, Activity and Solvency

Karikari Amoa-Gyarteng

Determinant Factors of Social Cohesion and Inclusion of Street Vendors in Jakarta: Key Factor Surviving During Covid-19 Pandemic

Beti Nurbaiti 


\title{
Subprime Crisis - A Corporate Acquisition Opportunity?
}

\author{
Vishal Srivastava* \\ Sunder Ram Korivit \\ Dipasha Sharma $¥$
}

\begin{abstract}
Corporate acquisition can be considered as one of the best processes of corporate restructuring. This study is focused to evaluate the post-acquisition operating performance of listed Indian companies (acquirers) which have made acquisitions during subprime crisis period i.e. from FY 2007-08 to FY 2009-10. Paired sample t-test has been used on four operating performance indicators i.e. return on equity (ROE), return on assets (ROA), operating profit margin (OPM) and operating cash flow to net sales ratio (OCF/NS) to check whether operating performance of acquirers has significantly improved post-acquisition. This study has revealed that there is no significant improvement in firms' operating performance based on financial parameters i.e. return on equity, return on assets and operating profit margin, post corporate acquisitions made during subprime crisis period and there was negative impact based on these parameters. Though operating cash flow to net sales ratio has improved significantly for the companies which have made acquisition in FY 2007-08 and FY 2008-09 but similar findings could not be achieved for FY 2009-10. This study will find its significance in present scenario wherein corporate acquisitions are seen as the fastest way to achieve growth. Corporate world may derive its growth strategy from this study.
\end{abstract}

Keywords: acquisition, accounting, corporate, inorganic, operating performance, subprime crisis.

\section{INTRODUCTION}

Subprime mortgage crisis though happened in Unites States between 2007-2010, has impacted the whole world and brought global recession to world economy. It is interesting to note that even during Sub-prime mortgage crisis (December 2007 to June 2009) which triggered the global recession, Indian companies remained bullish for achieving exponential growth by the way of acquisitions across all the business verticals not only in India but cross border as well. Hence, it becomes very important to evaluate the performance of acquiring companies in the later years also which have made acquisitions during sub-prime crisis. Neethu et al. (2018) found that there was an intense M\&A activity by Indian companies during the period of subprime crisis. Reddy et al. (2014) have found that 2007-2008 global financial crisis had negative impact on

\footnotetext{
* Ph.D. Scholar, under the Faculty of Management Symbiosis Centre for Research \& Innovation (SCRI), Symbiosis International (Deemed University), Gram: Lavale, Tal: Mulshi, Distt. Pune 412115 (Maharashtra), India. E-mail: vishalsr7@gmail.com.

+ Senior consultant, Department of Economic Affairs and National Institute of Financial Management Research Programme, Faridabad (NCR Delhi), India. E-mail: sundfina9 (a)gmail.com.

$\ddagger$ Ph.D. (Banking Finance, IIT Roorkee). Assistant professor, Finance Symbiosis Centre for Management \& Human Resource Development, Plot No. 15, Rajiv Gandhi Infotech Park, Hinjewadi, MIDC, Distt. Pune-411057 (Maharashtra), India. E-mail: dipashasharma20 @gmail.com.
} 
both cross-border mergers and acquisitions transactions all over the world from 2008 to 2009 .

It is now undebatable that adopting inorganic way of growth i.e. external expansion by mergers and acquisitions, has completely changed the business scenario across the world. Entry into various geographical markets along with building the scale can be achieved by acquisitions. This increases the globalization of businesses many times within a very short span of time. Acquisitions are seen as one of the best processes of corporate restructuring and it has acquired much importance in today's corporate world.

Previous research has shown that corporate acquisitions had positive, negative or no, and mixed impact on the performance of acquiring companies. The same has been elaborated under literature review section. This study finds various gaps in previous studies exploring post-acquisition performance of acquiring companies. Most of the researchers have considered only one (in few cases two) parameter to check the operating performance (post-acquisition) in their studies i.e. ROA or ROE or operating cash flow etc. The studies by many researchers are limited to one sector only i.e. banking, pharmaceuticals etc. The studies by some researchers are limited with in one country only. The sample size in studies by some researchers is very small, hence it is difficult to generalize the findings. In Indian context, very limited research has been done to study the post-acquisition operating performance of the acquiring companies that too which have been made during subprime crisis period. In Indian context, some researchers have limited their studies to the extent of few companies only. Any research work could not be located to judge the post-acquisition performance of the all the Indian companies which have done acquisitions in between FY 2007- 08 to FY 2009-10 i.e. the period of subprime crisis.

This study focuses to assess the acquirers' (listed Indian companies) performance post-acquisition those have made acquisitions during subprime crisis i.e. from financial year 2007-08 to FY 2009-10. Considering the urge amongst Indian companies to go for acquisition, this study will be very significant for corporate India while deciding the acquisition as a strategy for growth during such period of global crisis. This study will be an eye opener for corporate world to understand whether acquisitions really add value to stakeholders or merely it satisfies the managerial hubris.

\subsection{Objective of the Study}

Main objective of this study is to find out post-acquisition operating performance of listed Indian companies which made acquisitions during subprime crisis period i.e. from FY 2007-08 to FY 2009-10.

This study has been organized as follows:

1) Section 1 of this study has given brief introduction of corporate acquisitions and sub-prime mortgage crisis, impact of corporate acquisitions on acquiring companies and research gaps, and objective of this study.

2) Section 2 of the study discusses the various corporate acquisitions' studies based on sub-prime crisis period and other studies based on accounting method to evaluate the post-acquisition operating performance. This section also discusses formulation of hypotheses. In previous literature, the terms merger and acquisition have been interchangeably used by many authors, the same will be followed in this study also but the basic intent will remain as acquisition only. 
3) Section 3 elaborates about the research design and methodology which includes scope of study, data collection, sample of the study and finally the methodology used in this paper to compare performances before and after crisis.

4) Section 4 is data analysis and findings part of the paper.

5) Section 5 presents the discussion of the results.

6) Section 6 provides conclusion of the paper including limitation and future scope of this study.

\section{LITERATURE REVIEW AND HYPOTHESES DEVELOPMENT}

Substantial amount of research has been done to assess the performance of acquirers and various researchers have used different methods to assess the acquisitions' performance. Bruner (2002) summarized the evidences from 14 informal studies and 100 scientific studies from 1971 to 2001. He found following four approaches used by researchers in order to evaluate the post-acquisition performance.

1) Accounting studies (returns estimated from reported financial statements).

2) Event studies (market based returns to shareholders).

3) Clinical studies (case studies method).

4) Survey of executives (questionnaire method).

Many studies in this field have been done by using mixed method approach also in which the researcher has used two or more methods to evaluate the post-acquisition performance.

\subsection{Mixed Method Approach}

Accounting studies have been followed widely by the researchers which focus on pre- and post- acquisition financial performance indicators of the acquiring companies. Researchers have studied various parameters like return of equity (ROE), return on assets (ROA), net income, earnings per share (EPS) and cash flow etc. In these studies, the question is whether the acquirers outperformed their non-acquirer peers (Bruner, 2002). Accounting studies use audited financial statements of companies, hence the credibility of these studies can be very well established and unlike Event studies, these are not very much carried away by external events.

Various studies have shown that corporate acquisitions have positive impact on the firm's performance (Kaplan, 1989; Cornett \& Tehranian, 1992; Linder \& Crane, 1993; Switzer, 1996; Parrino \& Harris, 1999; Ramaswamy \& Waegelein, 2003; Rahman \& Limmack, 2004; Ramakrishnan, 2008; and Guestet al., 2010). In a path breaking research, Healy et al. (1992) have studied 50 biggest acquisitions, happened between 1979 to 1983, to assess the operating performance after merger for U.S. industrial firms. They used pre tax operating cash flow to measure the improvement in operating performance. They found that merged firms have significant improvement in operating cash flow returns after merger.

An interesting study by Fassin and Gosselin (2011) has concluded that Fortis, which has completed several successful mergers of companies in banking and insurance sector, collapsed after one year of acquisition of ABN AMRO, a Dutch financial conglomerate due to the financial crisis which spread globally. Other corporate acquistion studies have also shown negative or no impact (Melicher \& Rush, 1974; Ravenscraft \& Scherer, 1987, 1989; Clark \& Ofek, 1994; Dickerson et al., 1997; Healy et al., 1997; Kaplan et al., 2000; Ghosh, 2001; Sharma \& Ho, 2002; Akben-Selcuk \& Altiok-Yilmaz, 2011; Bertrand \& Betschinger, 2012; and Ferrer, 2012). 
Wan and Yiu (2009) found a positive relation of firm's performance with corporate acquisitions during an environmental jolt, but the same is negative before and after a jolt. Other studies on corporate acquistions have also shown mixed impact (Manson et al., 2000; Cosh \& Guest, 2001; Gugler et al., 2003; Linn \& Switzer, 2001; Pawaskar, 2001; Zollo \& Singh, 2004; Mantravadi \& Reddy, 2008; Martynova \& Renneboog, 2008; Mishra \& Chandra, 2010; and Kumara \& Satyanarayana, 2013).

\subsection{Formulation of Hypotheses}

Based on the research gaps identified, following research hypotheses have been formulated to fulfil the objective of study as mentioned above:

$\mathbf{H} 1_{0}$ : there is a significant improvement in the return on equity of acquiring companies (post-acquisition).

$\mathbf{H} \mathbf{2}_{0}$ : there is a significant improvement in the return on assets of acquiring companies (post-acquisition).

$\mathbf{H} 3_{0}$ : there is a significant improvement in the operating profit margin of acquiring companies (post-acquisition).

$\mathbf{H} 4_{0}$ : there is a significant improvement in the operating cash flow/net sales ratio of acquiring companies (post-acquisition).

\section{RESEARCH SAMPLE AND METHODOLOGY}

\subsection{Scope and Data Collection Methodology}

This study covers all the Listed Indian Companies (acquirers) which have made either domestic or cross-border acquisitions from FY 2007-08 to FY 2009-10.Target companies can be either Listed or Non-listed entities. Study keeps it focus only on completed acquisitions and includes only those acquisitions after which the financials of the target company start getting reported under the acquiring company i.e. either the target company (or part of it) merged with acquirer or target company becomes a subsidiary company of acquirer. For the proposed study, secondary data has been used and list of Indian companies which have done M\&A deals, collected from Bloomberg Terminal for FY 2007-08, FY 2008-09 and FY 2009-10.The list obtained from Bloomberg was having Mergers and Acquisitions both, hence, in order to find the only acquisition deals, annual/quarterly/monthly issues of Deal Tracker magazine (published by Grant Thronton, India) have been referred in order to find acquisition deals. Acquisition deals (domestic and cross border) appearing in "Deal Tracker" have been verified from the list obtained from Bloomberg in order to ensure that it is acquisition deal only. The deals in which more than $50 \%$ stake have been acquired by acquirer, only considered for study. From the obtained list (as mentioned above), companies listed at national stock exchange (NSE) or Bombay stock exchange (BSE) have been sorted out. If any company has made multiple acquisitions in a particular financial year, its name has been considered only one time for that particular financial year. This has given the final list of companies to be used for this study for financial years 2007-08, 2008-09 and 2009-10 Data from CMIE-prowess database has been collected for all the above-mentioned companies in order to derive following operating performance indicators:

Insert Table 1 here.

The study excludes finance companies because of their high leverage arising out of nature of business. The number of companies for which comparable data is available (excluding finance sector companies and outliers) are minimum as follows for the respective financial year: 
Table 1

Operating Performance Indicators

\begin{tabular}{|c|c|c|c|}
\hline $\begin{array}{l}\text { S. } \\
\text { No. }\end{array}$ & $\begin{array}{l}\text { Operating } \\
\text { Performance } \\
\text { Indicator } \\
\end{array}$ & Formula & $\begin{array}{l}\text { Input from } \\
\text { CMIE-Prowess }\end{array}$ \\
\hline 1. & $\begin{array}{l}\text { Return on } \\
\text { Equity (ROE) }\end{array}$ & $\frac{\text { Net Income or Profit after Tax (PAT) }}{\text { Shareholders' Equity }}$ & $\begin{array}{l}\text { Directly Available. } \\
\text { Total Capital+Reserves and } \\
\text { Funds. }\end{array}$ \\
\hline 2. & $\begin{array}{l}\text { Return on } \\
\text { Assets (ROA) }\end{array}$ & $\frac{\text { Net Income or Profit after Tax (PAT) }}{\text { Total Assets }}$ & Directly Available. \\
\hline 3. & $\begin{array}{l}\text { Operating } \\
\text { Profit Margin } \\
\text { (OPM) }\end{array}$ & $\frac{\text { Profit before Interest and Taxes (PBIT) }}{\text { Net Sales }}$ & $\begin{array}{l}\text { PAT+Provision for direct } \\
\text { tax }+ \text { Interest expense }+ \\
\text { Financial charges on Debt } \\
\text { Instruments+Bill discounting } \\
\text { charges. } \\
\text { Directly available. }\end{array}$ \\
\hline 4. & $\begin{array}{l}\text { Operating } \\
\text { Cash Flow to } \\
\text { Net Sales } \\
\text { Ratio (OCF/ } \\
\text { Net Sales) }\end{array}$ & $\frac{\text { Net Cash Flow from Operating Activities }}{\text { Net Sales }}$ & Directly Available. \\
\hline
\end{tabular}

Source: CMIE-prowess.

Table 2

Financial Year Wise Number of Companies (Minimum)

$\begin{array}{lc}\text { FY 2007-08 } & 152 \text { Nos. } \\ \text { FY 2008-09 } & 120 \text { Nos. } \\ \text { FY 2009-10 } & 93 \text { Nos. }\end{array}$

Source: authors' analysis.

Hence, for all the three financial years, total 365 nos. acquiring companies (minimum) have been obtained and are being examined under this study. Inputs from the CMIE-prowess have been collected for all the three years pre and post-acquisition including the year in which acquisition took place i.e. the range of data to be used for this study is as follows:

Table 3

Financial Year Wise Data Range

$\begin{array}{ll}\text { FY 2007-08 } & \text { From FY 2004-05 to FY 2010-11 } \\ \text { FY 2008-09 } & \text { From FY 2005-06 to FY 2011-12 } \\ \text { FY 2009-10 } & \text { From FY 2006-07 to FY 2012-13 }\end{array}$

Source: authors' analysis.

\subsection{Methodology Used to Compare Performances Pre and Post Crisis}

In the year when the acquisition happened, has been considered as ZERO. A period of three years after acquisition has been chosen for study because it is sufficient time for the reflection of benefits, reaching of synergy, if any, in the operating performance of acquiring companies. Researchers like Cornett and Tehranian (1992), Ghosh (2001), Pawaskar (2001), Zollo and Singh (2004), and Mantravadi and Reddy (2008) have also used a span of three years in their studies.

Most of the previous studies (Ravenscraft \& Scherer, 1987, 1989; Kaplan, 1989; Cornett \& Tehranian, 1992; Linder \& Crane, 1993; Switzer, 1996; Dickerson et al., 1997; Healy et al., 1997; Parrino \& Harris, 1999; Manson et al., 2000; Cosh \& Guest, 
2001; Ghosh, 2001; Gugler et al., 2003; Linn \& Switzer, 2001; Sharma \& Ho, 2002; Rahman \& Limmack, 2004; Zollo \& Singh, 2004; Mantravadi \& Reddy, 2008; Ramakrishnan, 2008; Wan \& Yiu, 2009; Guest et al., 2010; Akben-Selcuk \& AltiokYilmaz, 2011; Bertrand \& Betschinger, 2012; and Kumara \& Satyanarayana, 2013) have used either ROE, ROA, OPM, and OCF/net sales ratio. Hence, this study will focus to know the impact on all the mentioned parameters i.e. ROE, ROA, OPM, and OCF/net sales ratio of the acquiring companies, post-acquisition for a comprehensive outcome.

After collection of all the inputs from CMIE-prowess, operating performance indicators have been calculated by using the above-mentioned formulas for FY 200708, FY 2008-09 and FY 2009-10. After calculation of mentioned operating performance indicators, mean for every indicator has been calculated for the data obtained for each set of year zero i.e. we have one set of data for every financial year under study. Hence, finally we have three sets of data (one set for each financial year). Since, we want to compare the means of individual performance indicators of same acquiring companies during pre- and post-acquisition period, paired sample two tailed t-test will be the most suitable for this purpose. Researchers like Pawaskar (2001), Mantravadi and Reddy (2008) have used paired sample two tailed t-test in their studies. For FY 2007-08, we have tested the hypotheses with paired sample two tailed t-test (at $95 \%$ confidence interval) to find out whether performance indicators under study have improved significantly during post-acquisition period. In the similar manner, we have tested the hypotheses for FY 2008-09 and FY 2009-10. We have got one set of result for each financial year i.e. FY 2007-08, FY 2008-09 and FY 2009-10.

\section{EMPIRICAL RESULTS}

\subsection{Data Analysis}

\subsubsection{Analysis based on return on equity (ROE)}

Table 4

Summary Based on ROE

\begin{tabular}{|c|c|c|c|c|}
\hline $\begin{array}{l}\text { S. } \\
\text { No. }\end{array}$ & Particulars & $\begin{array}{c}\text { Financial } \\
\text { Year } \\
2007-08\end{array}$ & $\begin{array}{c}\text { Financial } \\
\text { Year } \\
2008-09\end{array}$ & $\begin{array}{c}\text { Financial } \\
\text { Year } \\
2009-10\end{array}$ \\
\hline 1. & Total no. of companies shortlisted & 222 & 175 & 157 \\
\hline 2. & $\begin{array}{l}\text { No. of companies for which comparable } \\
\text { data is not available }\end{array}$ & 42 & 27 & 36 \\
\hline 3. & No. of finance sector companies & 11 & 11 & 9 \\
\hline 4. & No. of companies having outlier data & 17 & 16 & 19 \\
\hline 5. & $\begin{array}{l}\text { Companies considered for this study after } \\
\text { excluding S. No. } 2,3 \text { \& } 4 \text { (i.e. } 1-2-3-4 \text { ) }\end{array}$ & 152 & 121 & 93 \\
\hline 6. & No. of companies shown increase in ROE & 35 & 23 & 19 \\
\hline 7. & No. of companies shown decrease in ROE & 117 & 98 & 74 \\
\hline
\end{tabular}

Source: authors' analysis.

From the above table, it is clearly visible that number of companies which have shown increase in ROE after acquisition are considerably lower than which have shown decrease after the same for all the three financial years under study. We have tested the hypotheses with paired sample two tailed t-test (at 95\% confidence interval) to find out whether there is a significant improvement on the performance indicators under study during post-acquisition period. A year wise analysis (Table 5) can be summarized as follows: 
Table 5

Impact of Corporate Acquisitions on Return on Equity (ROE) - Hypothesis Testing

\begin{tabular}{|c|c|c|c|c|c|c|c|c|c|c|}
\hline $\begin{array}{c}\text { S. } \\
\text { No. }\end{array}$ & $\begin{array}{l}\text { Financi- } \\
\text { al Year }\end{array}$ & $\begin{array}{c}\text { No. of } \\
\text { Compa- } \\
\text { nies }\end{array}$ & $\begin{array}{c}\text { ROE } \\
\text { Mean } \\
\text { (3 years } \\
\text { before } \\
\text { acquisi- } \\
\text { tion) }\end{array}$ & $\begin{array}{c}\text { ROE } \\
\text { Mean } \\
\text { (3 years } \\
\text { after } \\
\text { acquisi- } \\
\text { tion) }\end{array}$ & $\begin{array}{c}\mathrm{t} \\
(.05 \\
\text { signify } \\
\text {-cance })\end{array}$ & $\begin{array}{l}\text { p-value } \\
\text { Sig. } \\
(2- \\
\text { tailed) }\end{array}$ & $\begin{array}{c}\text { e Change in } \\
\text { ROE } \\
\text { (Increase / } \\
\text { Decrease) }\end{array}$ & $\begin{array}{l}\text { Whether } \\
\text { Signifi- } \\
\text { cant } \\
\text { (Yes/ } \\
\text { No) }\end{array}$ & $\begin{array}{c}\text { Null } \\
\text { Hypo- } \\
\text { thesis } \\
\text { Applica- } \\
\text { ble }\end{array}$ & $\begin{array}{c}\text { Null } \\
\text { Hypo- } \\
\text { thesis } \\
\text { (Accept/ } \\
\text { Reject) }\end{array}$ \\
\hline 1. & $\begin{array}{c}\text { FY } \\
2007-08\end{array}$ & 152 & $20.36 \%$ & $12.16 \%$ & 7.175 & $<0.05$ & Decrease & Yes & $\mathrm{H} 1_{0}$ & Reject \\
\hline 2. & $\begin{array}{c}\text { FY } \\
\text { 2008-09 }\end{array}$ & 121 & $20.50 \%$ & $11.28 \%$ & 9.02 & $<0.05$ & Decrease & Yes & $\mathrm{H} 1_{0}$ & Reject \\
\hline 3. & $\begin{array}{c}\text { FY } \\
2009-10\end{array}$ & 93 & $18.45 \%$ & $8.14 \%$ & 7.381 & $<0.05$ & Decrease & Yes & $\mathrm{H} 1_{0}$ & Reject \\
\hline
\end{tabular}

Source: authors' calculations.

1). All the companies for which data is available (excluding finance sector companies and outliers)

Paired sample t-test for all the companies for which data is available (excluding finance sector and outliers) in FY 2007-08 has shown that mean ROE for three years before and after acquisition is $20.36 \%$ and $12.16 \%$ respectively. Hence there is a decrease in mean ROE after acquisition and it is statistically significant ( $\mathrm{p}$-value is < 0.05 and $t=7.175)$ also.

Paired sample t-test for all the companies for which data is available (excluding finance sector and outliers) in FY 2008-09 has shown that mean ROE for three years before and after acquisition is $20.50 \%$ and $11.28 \%$ respectively. Hence there is a decrease in mean ROE after acquisition and it is statistically significant ( $p$-value is $<$ 0.05 and $\mathrm{t}=0.02)$ also.

Paired sample t-test for all the companies for which data is available (excluding finance sector and outliers) in FY 2009-10 has shown that mean ROE for three years before and after acquisition is $18.45 \%$ and is $8.14 \%$ respectively. Hence there is a decrease in mean ROE after acquisition and it is statistically significant ( $\mathrm{p}$-value is < 0.05 and $t=7.381$ ) also. Hence, based on the above analysis, hypothesis $\mathrm{H} 1_{0}$ : "there is a significant improvement in the return on equity of acquiring companies (postacquisition)" is rejected.

\subsubsection{Analysis based on return on assets (ROA)}

Table 6

Summary Based on ROA

\begin{tabular}{|c|c|c|c|c|}
\hline $\begin{array}{l}\text { S. } \\
\text { No. }\end{array}$ & Particulars & $\begin{array}{c}\text { Financial } \\
\text { Year } \\
2007-08\end{array}$ & $\begin{array}{c}\text { Financial } \\
\text { Year } \\
2008-09\end{array}$ & $\begin{array}{c}\text { Financial } \\
\text { Year } \\
2009-10\end{array}$ \\
\hline 1. & Total No. of companies shortlisted & 222 & 175 & 157 \\
\hline 2. & $\begin{array}{l}\text { No. of companies for which comparable } \\
\text { data is not available }\end{array}$ & 40 & 27 & 36 \\
\hline 3. & No. of finance companies & 11 & 11 & 9 \\
\hline 4. & No. of companies having outlier data & 17 & 17 & 19 \\
\hline 5. & $\begin{array}{l}\text { Companies considered for this study after } \\
\text { excluding S. No. } 2,3 \& 4 \text { (i.e. } 1-2-3-4 \text { ) }\end{array}$ & 154 & 120 & 93 \\
\hline 6. & No. of companies shown increase in ROA & 29 & 25 & 24 \\
\hline 7. & No. of companies shown decrease in ROA & 125 & 95 & 69 \\
\hline
\end{tabular}

Source: authors' analysis. 
From the above table, it is clearly visible that number of companies which have shown increase in ROA after acquisition are considerably lower than which have shown decrease after the same for all the three financial years under study. We have tested the hypotheses with paired sample two tailed t-test (at 95\% confidence interval) to find out whether there is a significant improvement on the performance indicators under study during post-acquisition period. A year wise analysis (Table 7) can be summarized as follows:

\section{1). All the companies for which data is available (excluding finance sector companies and outliers)}

Paired sample t-test for all the companies for which data is available (excluding finance sector and outliers) in FY 2007-08 has shown that mean ROA for three years before and after acquisition is $8.23 \%$ and $4.99 \%$ respectively. Hence there is a decrease in mean ROA after acquisition and it is statistically significant ( $\mathrm{p}$-value is $<0.05$ and $\mathrm{t}=$ 8.462) also.

Table 7

Impact of Corporate Acquisitions on Return on Assets (ROA) - Hypothesis Testing

\begin{tabular}{|c|c|c|c|c|c|c|c|c|c|c|}
\hline $\begin{array}{l}\text { S. } \\
\text { No. }\end{array}$ & $\begin{array}{l}\text { Financi- } \\
\text { al Year }\end{array}$ & $\begin{array}{c}\text { No. of } \\
\text { Compa- } \\
\text { nies }\end{array}$ & $\begin{array}{c}\text { ROA } \\
\text { Mean } \\
\text { (3 years } \\
\text { before } \\
\text { acquisi- } \\
\text { tion) }\end{array}$ & $\begin{array}{c}\text { ROA } \\
\text { Mean } \\
\text { (3 years } \\
\text { after } \\
\text { acquisi- } \\
\text { tion) }\end{array}$ & $\begin{array}{c}\mathrm{t} \\
(.05 \\
\text { signify } \\
\text {-cance) }\end{array}$ & $\begin{array}{c}\text { p-value } \\
\text { Sig. } \\
(2- \\
\text { tailed })\end{array}$ & $\begin{array}{c}\text { Change in } \\
\text { ROA } \\
\text { (Increase/ } \\
\text { Decrease) }\end{array}$ & $\begin{array}{l}\text { Whether } \\
\text { Signifi- } \\
\text { cant } \\
\text { (Yes/ } \\
\text { No) }\end{array}$ & $\begin{array}{c}\text { Null } \\
\text { Hypo- } \\
\text { thesis } \\
\text { Applica- } \\
\text { ble }\end{array}$ & $\begin{array}{c}\text { Null } \\
\text { Hypo- } \\
\text { thesis } \\
\text { (Accept/ } \\
\text { Reject) }\end{array}$ \\
\hline 1. & $\begin{array}{c}\text { FY } \\
2007-08\end{array}$ & 154 & $8.23 \%$ & $4.99 \%$ & 8.462 & $<0.05$ & Decrease & Yes & $\mathrm{H} 2_{0}$ & Reject \\
\hline 2. & $\begin{array}{c}\text { FY } \\
2008-09\end{array}$ & 120 & $8.90 \%$ & $5.09 \%$ & 8.513 & $<0.05$ & Decrease & Yes & $\mathrm{H} 2_{0}$ & Reject \\
\hline 3. & $\begin{array}{c}\text { FY } \\
2009-10\end{array}$ & 93 & $7.45 \%$ & $3.69 \%$ & 6.557 & $<0.05$ & Decrease & Yes & $\mathrm{H} 2_{0}$ & Reject \\
\hline
\end{tabular}

Source: authors' calculations.

Paired sample t-test for all the companies for which data is available (excluding finance sector and outliers) in FY 2008-09 has shown that mean ROA for three years before and after acquisition is $8.90 \%$ and $5.09 \%$ respectively. Hence there is a decrease in mean ROA after acquisition and it is statistically significant ( $\mathrm{p}$-value is $<0.05$ and $\mathrm{t}=$ 8.513) also.

Paired sample t-test for all the companies for which data is available (excluding finance sector and outliers) in FY 2009-10 has shown that mean ROA for three years before and after acquisition is $7.45 \%$ and $3.69 \%$ respectively. Hence there is a decrease in mean ROA after acquisition and it is statistically significant ( $\mathrm{p}$-value is $<0.05$ and $\mathrm{t}=$ 6.557) also.

Hence, based on the above analysis, hypothesis $\mathrm{H} 2_{0}$ : "there is a significant improvement in the return on assets of acquiring companies (post-acquisition)" is rejected.

\subsubsection{Analysis based on operating profit margin (OPM)}

Insert Table 8 here.

From the above table, it is clearly visible that number of companies which have shown increase in OPM after acquisition are considerably lower than which have shown decrease after the same for all the three financial years under study. We have tested the hypotheses with paired sample two tailed t-test (at 95\% confidence interval) to find out whether there is a significant improvement on the performance indicators under study during post-acquisition period. A year wise analysis (Table 9) can be summarized as follows: 
Table 8

Summary Based on OPM

\begin{tabular}{|c|c|c|c|c|}
\hline $\begin{array}{l}\text { S. } \\
\text { No. }\end{array}$ & Particulars & $\begin{array}{c}\text { Financial } \\
\text { Year } \\
2007-08\end{array}$ & $\begin{array}{c}\text { Financial } \\
\text { Year } \\
2008-09\end{array}$ & $\begin{array}{c}\text { Financial } \\
\text { Year } \\
2009-10\end{array}$ \\
\hline 1. & Total no. of companies shortlisted & 222 & 175 & 157 \\
\hline 2. & $\begin{array}{l}\text { No. of companies for which comparable data } \\
\text { is not available }\end{array}$ & 46 & 30 & 39 \\
\hline 3. & No. of finance companies & 7 & 8 & 6 \\
\hline 4. & No. of companies having outlier data & 17 & 16 & 18 \\
\hline 5. & $\begin{array}{l}\text { Companies considered for this study after } \\
\text { excluding S. No. } 2,3 \text { \& } 4 \text { (i.e. } 1-2-3-4 \text { ) }\end{array}$ & 152 & 121 & 94 \\
\hline 6. & No. of companies shown increase in OPM & 52 & 40 & 28 \\
\hline 7. & No. of companies shown decrease in OPM & 100 & 81 & 66 \\
\hline
\end{tabular}

Source: authors' analysis.

1). All the companies for which data is available (excluding finance sector companies and outliers)

Paired sample t-test for all the companies for which data is available (excluding finance sector and outliers) in FY 2007-08 has shown that mean OPM for three years before and after acquisition is $17.23 \%$ and $13.81 \%$ respectively. Hence there is a decrease in mean OPM after acquisition but it is not statistically significant ( $\mathrm{p}$-value is $>$ 0.05 and $t=5.234)$.

Paired sample t-test for all the companies for which data is available (excluding finance sector and outliers) in FY 2008-09 has shown that mean OPM for three years before and after acquisition is $16.90 \%$ and $13.08 \%$ respectively.

Hence there is a decrease in mean OPM after acquisition and it is statistically significant ( $\mathrm{p}$-value is $<0.05$ and $\mathrm{t}=5.301)$ also.

Table 9

Impact of Corporate Acquisitions on Operating Profit Margin (OPM) - Hypothesis Testing

\begin{tabular}{|c|c|c|c|c|c|c|c|c|c|c|}
\hline $\begin{array}{c}\text { S. } \\
\text { No. }\end{array}$ & $\begin{array}{l}\text { Financi- } \\
\text { al Year }\end{array}$ & $\begin{array}{l}\text { No. of } \\
\text { Compa- } \\
\text { nies }\end{array}$ & $\begin{array}{c}\text { OPM } \\
\text { Mean } \\
\text { (3 years } \\
\text { before } \\
\text { acquisi- } \\
\text { tion) }\end{array}$ & $\begin{array}{c}\text { OPM } \\
\text { Mean } \\
\text { (3 years } \\
\text { after } \\
\text { acquisi- } \\
\text { tion) }\end{array}$ & $\begin{array}{c}\mathrm{t} \\
(.05 \\
\text { signify } \\
\text {-cance })\end{array}$ & $\begin{array}{l}\text { p-value } \\
\text { Sig. } \\
\text { (2- } \\
\text { tailed) }\end{array}$ & $\begin{array}{c}\text { Change in } \\
\text { OPM } \\
\text { (Increase/ } \\
\text { Decrease) }\end{array}$ & $\begin{array}{l}\text { Whether } \\
\text { Signifi- } \\
\text { cant } \\
\text { (Yes/ } \\
\text { No) }\end{array}$ & $\begin{array}{l}\text { Null } \\
\text { Hypo- } \\
\text { thesis } \\
\text { Applica- } \\
\text { ble }\end{array}$ & $\begin{array}{c}\text { Null } \\
\text { Hypo- } \\
\text { thesis } \\
\text { (Accept/ } \\
\text { Reject) }\end{array}$ \\
\hline 1. & $\begin{array}{c}\text { FY } \\
2007-08\end{array}$ & 152 & $17.23 \%$ & $13.81 \%$ & 5.234 & $>0.05$ & Decrease & No & $\mathrm{H} 3_{0}$ & Reject \\
\hline 2. & $\begin{array}{c}\text { FY } \\
2008-09\end{array}$ & 121 & $16.90 \%$ & $13.08 \%$ & 5.301 & $<0.05$ & Decrease & Yes & $\mathrm{H} 3_{0}$ & Reject \\
\hline 3. & $\begin{array}{c}\text { FY } \\
2009-10\end{array}$ & 94 & $16.79 \%$ & $11.05 \%$ & 5.657 & $<0.05$ & Decrease & Yes & $\mathrm{H} 3_{0}$ & Reject \\
\hline
\end{tabular}

Source: authors' calculations.

Paired sample t-test for all the companies for which data is available (excluding finance sector and outliers) in FY 2009-10 has shown that mean OPM for three years before and after acquisition is $16.79 \%$ and $11.05 \%$ respectively. Hence there is a decrease in mean OPM after acquisition and it is statistically significant ( $\mathrm{p}$-value is < 0.05 and $t=5.657$ ) also.

Hence, based on the above analysis, hypothesis $\mathrm{H} 3_{0}$ : "there is a significant improvement in the operating profit margin of acquiring companies (post-acquisition)" is rejected. 


\subsubsection{Analysis based on OCF/Net Sales Ratio}

\section{Table 10}

Summary Based on OCF/Net Sales Ratio

\begin{tabular}{|c|c|c|c|c|}
\hline $\begin{array}{l}\text { S. } \\
\text { No. }\end{array}$ & Particulars & $\begin{array}{c}\text { Financial } \\
\text { Year } \\
2007-08\end{array}$ & $\begin{array}{c}\text { Financial } \\
\text { Year } \\
2008-09\end{array}$ & $\begin{array}{c}\text { Financial } \\
\text { Year } \\
2009-10\end{array}$ \\
\hline 1. & Total no. of companies shortlisted & 222 & 175 & 157 \\
\hline 2. & $\begin{array}{l}\text { No. of companies for which comparable } \\
\text { data is not available }\end{array}$ & 47 & 30 & 41 \\
\hline 3. & No. of finance companies & 7 & 8 & 6 \\
\hline 4. & No. of companies having outlier data & 15 & 16 & 7 \\
\hline 5. & $\begin{array}{l}\text { Companies considered for this study after } \\
\text { excluding S. No. } 2,3 \text { \& } 4 \text { (i.e. } 1-2-3-4 \text { ) }\end{array}$ & 153 & 121 & 103 \\
\hline 6. & $\begin{array}{l}\text { No. of companies shown increase in } \\
\text { OCF/net sales }\end{array}$ & 89 & 75 & 46 \\
\hline 7. & $\begin{array}{l}\text { No. of companies shown decrease in } \\
\text { OCF/net sales }\end{array}$ & 64 & 46 & 57 \\
\hline
\end{tabular}

Source: authors' analysis.

From the above table, it is clearly visible that number of companies which have shown increase in OCF/net Sales ratio after acquisition are more for FY 2007-08 and FY 2008-09 than which have shown decrease after the same. However, for FY 2009-10, number of companies which have shown increase in OCF/net Sales ratio after acquisition are less than which have shown decrease after the same. We have tested the hypotheses with paired sample two tailed t-test (at 95\% confidence interval) to find out whether there is a significant improvement on the performance indicators under study during post-acquisition period. A year wise analysis (Table 11) can be summarized as follows:

\section{1). All the companies for which data is available (excluding finance sector companies and outliers)}

Paired sample t-test for all the companies for which data is available (excluding finance sector and outliers) in FY 2007-08 has shown that mean OCF/net sales ratio for three years before and after acquisition is $10.33 \%$ and $12.76 \%$ respectively. Hence there is an increase in mean $\mathrm{OCF} /$ net sales ratio after acquisition and it is statistically significant ( $\mathrm{p}$-value is $<0.05$ and $\mathrm{t}=-2.651$ ) also.

Paired sample t-test for all the companies for which data is available (excluding finance sector and outliers) in FY 2008-09 has shown that mean OCF/net sales ratio for three years before and after acquisition is $8.82 \%$ and $12.01 \%$ respectively. Hence there is an increase in mean OCF/Net Sales ratio after acquisition and it is statistically significant ( $\mathrm{p}$-value is $<0.05$ and $\mathrm{t}=-3.084$ ) also.

Insert Table 11 here.

Paired sample t-test for all the companies for which data is available (excluding finance sector and outliers) in FY 2009-10 has shown that mean OCF/net sales ratio for three years before and after acquisition is $13.22 \%$ and $9.70 \%$ respectively. Hence there is a decrease in mean $\mathrm{OCF} /$ net sales ratio after acquisition and it is statistically significant ( $\mathrm{p}$-value is $<0.05$ and $\mathrm{t}=2.046$ ) also.

Hence, based on the above analysis, hypothesis $\mathrm{H}_{0}$ : "there is a significant improvement in the OCF/net sales ratio of acquiring companies (post-acquisition)" is accepted for FY 2007-08 and FY 2008-09. However, hypothesis is rejected for FY 2009-10. 
Table 11

Impact of Corporate Acquisitions on Operating Cash Flow (OCF) to Net Sales Hypothesis Testing

\begin{tabular}{|c|c|c|c|c|c|c|c|c|c|c|}
\hline \multirow[b]{2}{*}{$\begin{array}{l}\text { S. } \\
\text { No. }\end{array}$} & \multirow[b]{2}{*}{$\begin{array}{c}\text { Financi- } \\
\text { al Year }\end{array}$} & \multicolumn{5}{|c|}{ OCF/Net OCF/Net } & \multirow[b]{2}{*}{$\begin{array}{c}\text { Change in } \\
\text { OCF/Net } \\
\text { Sales } \\
\text { (Increase/ } \\
\text { Decrease) }\end{array}$} & \multirow[b]{2}{*}{$\begin{array}{l}\text { Whether } \\
\text { Signifi- } \\
\text { cant } \\
\text { (Yes/ } \\
\text { No) }\end{array}$} & \multirow[b]{2}{*}{$\begin{array}{l}\text { Null } \\
\text { Hypo- } \\
\text { thesis } \\
\text { Applica- } \\
\text { ble }\end{array}$} & \multirow[b]{2}{*}{$\begin{array}{c}\text { Null } \\
\text { Hypo- } \\
\text { thesis } \\
\text { (Accept/ } \\
\text { Reject) }\end{array}$} \\
\hline & & $\begin{array}{l}\text { No. of } \\
\text { Compa } \\
\text {-nies }\end{array}$ & $\begin{array}{c}\text { Sales } \\
\text { Mean } \\
\text { (3 years } \\
\text { before } \\
\text { acquisi- } \\
\text { tion) }\end{array}$ & $\begin{array}{c}\text { Sales } \\
\text { Mean } \\
\text { (3 years } \\
\text { after } \\
\text { acquisi- } \\
\text { tion) }\end{array}$ & $\begin{array}{c}\mathrm{t} \\
(.05 \\
\text { signify } \\
\text {-cance })\end{array}$ & $\begin{array}{l}\text { p-value } \\
\text { Sig. } \\
\text { (2- } \\
\text { tailed) }\end{array}$ & & & & \\
\hline 1. & $\begin{array}{c}\text { FY } \\
2007-08\end{array}$ & 154 & $10.33 \%$ & $12.76 \%$ & -2.651 & $<0.05$ & Increase & Yes & $\mathrm{H} 4_{0}$ & Accept \\
\hline 2. & $\begin{array}{c}\text { FY } \\
2008-09\end{array}$ & 121 & $8.82 \%$ & $12.01 \%$ & -3.084 & $<0.05$ & Increase & Yes & $\mathrm{H}_{4}$ & Accept \\
\hline 3. & $\begin{array}{c}\text { FY } \\
2009-10\end{array}$ & 103 & $13.22 \%$ & $9.70 \%$ & 2.046 & $<0.05$ & Decrease & Yes & $\mathrm{H} 4_{0}$ & Reject \\
\hline
\end{tabular}

Source: authors' calculations.

\subsection{Research Discussion}

This study has been conducted to know the impact of acquisition on the acquiring companies on the mentioned parameters i.e. ROE, ROA, OPM and $\mathrm{OCF} /$ net sales ratio. These parameters have been very carefully selected based on the previous studies which have used either or few of them. Study finds that postacquisition, there is no significant improvement in the return on equity of acquiring companies and this is in line with the findings of Sharma and Ho (2002), Akben-Selcuk and Altiok-Yilmaz (2011) but it is in contrast to the findings of Guest et al. (2010). Study also finds that post-acquisition, there is no significant improvement in the return on assets of acquiring companies and this is in line with the findings of Dickerson et al. (1997), Sharma and Ho (2002), Mantravadi and Reddy (2008), Akben-Selcuk and Altiok-Yilmaz (2011), Bertrand and Betschinger (2012) but in contrast to the findings of Cornett and Tehranian (1992), Linder and Crane (1993). Study further finds that post-acquisition, there is a no significant improvement in the operating profit margin of acquiring companies and this is similar to the findings of Ravenscraft and Scherer (1987), Sharma and Ho (2002) but in contrast to the findings of Kaplan (1989), Cosh and Guest (2001), Gugler et al. (2003), Pawaskar (2001), and Ramakrishnan (2008). However finding for operating cash flow/net sales ratio is different from the other parameters. Study finds that there is a significant improvement in the operating cash flow/net sales ratio of acquiring companies (post-acquisition) for FY 2007-08 and FY 2008-09. However, same finding could not be achieved for FY 2009-10. Findings for FY 2007-08 and FY 2008-09 are in line with the findings of Kaplan (1989), Cornett and Tehranian (1992), Healy et al. (1992), Switzer (1996), Parrino and Harris (1999), Ramaswamy and Waegelein (2003), and Rahman and Limmack (2004) but the findings for FY 2009-10 are in line with the findings of Ravenscraft and Scherer (1987, 1989), Clark and Ofek (1994), Healy et al. (1997), Ghosh (2001), and Sharma and Ho (2002).

\section{CONCLUSION}

This study tries to find out the impact of corporate acquisitions, made by Indian listed companies during subprime crisis, on their operating performance. Previous literature available has been reviewed mainly keeping its focus on corporate acquisition studies based on accounting method. Previous literature has shown that acquisitions have positive, negative or no impact as well as a mixed impact (i.e. positive and negative 
both) on firms performance. However, this study has revealed that there is no significant improvement (negative impact) in the firms' operating performance based on financial parameters i.e. return on equity (ROE), return on assets (ROA) and operating profit margin (OPM), post corporate acquisitions made during subprime crisis period. Though operating cash flow to net sales ratio has improved significantly for the companies which have made acquisition in FY 2007-08 and FY 2008-09, similar findings could not be achieved for FY 2009-10. Hence, corporate acquisitions done by Indian companies during subprime crisis period have not added any value to firms' operating performance except for one parameter i.e. operating cash flow to net sales ratio during FY 2007-08 and FY 2008-09 wherein it has significantly increased postacquisitions. This study is limited to the pre and post-acquisition financial parameters of the acquiring Indian listed companies (during subprime crisis period) only since it is difficult to get the authentic data for the firm if it is a non-listed entity. This study excludes the effect of any change in law and regulation on the post- acquisition performance of acquiring companies. This study does not differentiate between cash and stock acquisitions. Based on the outcome of this study, future research can be carried out to understand whether it was only global financial crisis or other factors have also contributed in the post-acquisition operating performance of listed Indian acquiring companies. However, based on the above discussion, one thing can be said with lot of certainty that researchers will always remain keen on corporate acquisition studies and further scope for study will remain forever.

\section{REFERENCES}

Akben-Selcuk, E., \& Altiok-Yilmaz, A. (2011, February). The impact of mergers and acquisitions on acquirer performance: Evidence from Turkey. Business \& Economics Journal (BEJ), 22, 1-8.

Bertrand, O., \& Betschinger, M. -A. (2012). Performance of domestic and cross-border acquisitions: Empirical evidence from Russian acquirers. Journal of Comparative Economics, 40(3), 413-437.

Bruner, R. F. (2002). Does M\&A pay? A survey of evidence for the decision maker. Journal of Applied Finance, 12(1), 48-68.

Clark, K., \& Ofek, E. (1994). Mergers as a means of restructuring distressed firms: An empirical investigation. Journal of Financial \& Quantitative Analysis, 29(4), 541-565.

Cornett, M. M., \& Tehranian, H. (1992, April). Changes in corporate performance associated with bank acquisitions. Journal of Financial Economics, 31(2), 211-234.

Cosh, A. D., \& Guest, P. M. (2001, October). The long-run performance of hostile takeovers: UK evidence. Working papers (wp215), ESRC Centre fo Business Research, University of Cambridge, Cambridge-UK.

Dickerson, A. P., Gibson, H. D., \& Tsakalotos, E. (1997, February). The impact of acquisitions on company performance: Evidence from a large panel of UK firms. Oxford Economic Papers, 49(3), 344-361.

Fassin, Y., \& Gosselin, D. P. (2011, August). The collapse of a European bank in the financial crisis: An analysis from stakeholder and ethical perspectives. Journal of Business Ethics, 102(2), 169-191.

Ferrer, R. C. (2012, January). An empirical investigation of the effects of merger and acquisition on firm's profitability. Academy of Accounting \& Financial Studies Journal, 16(3), 31-55.

Ghosh, A. (2001, January). Does operating performance really improve following corporate acquisitions? Journal of Corporate Finance, 7(2), 151-178. 
Guest, P. M., Bild, M., \& Runsten, M. (2010, January). The effect of takeovers on the fundamental value of acquirers. Accounting \& Business Research, 40(4), 333-352.

Gugler, K., Mueller, D. C., Yurtoglu, B. B., \& Zulehner, C. (2003, May). The effects of mergers: An international comparison. International Journal of Industrial Organization, 21(5), 625-653.

Healy, P. M., Palepu, K. G., \& Ruback, R. S. (1992, April). Does corporate performance improve after mergers? Journal of Financial Economics, 31(2), 135-175.

Healy, P. M., Palepu, K. G., \& Ruback, R. S. (1997, July). Which takeovers are profitable? Strategic or financial? MIT Sloan Management Review, 38(4), 45-57.

Kaplan, S. (1989). The effect of management buyouts on operating performance and value. Journal of Financial Economics, 24(2), 217-254.

Kaplan, S. N., Mitchell, M. L, \& Wruck, K. H. (2000). A clinical exploration of value creation and destruction in acquisitions: Organizational design, incentives, and internal capital markets. In S. N. Kaplan, Mergers and productivity (pp. 179-238). National Bureau of Economic Research, Inc.

Kumara, N. M., \& Satyanarayana. (2013, March). Comparative study of pre and post corporate integration through mergers and acquisition. International Journal of Business \& Management Invention, 2(3), 31-38.

Linder, J. C., \& Crane, D. B. (1993, February). Bank mergers: Integration and profitability. Journal of Financial Services Research, 7(1), 35-55.

Linn, S. C., \& Switzer, J. A. (2001). Are cash acquisitions associated with better postcombination operating performance than stock acquisitions? Journal of Banking \& Finance, 25(6), 1113-1138.

Manson, S., Powel, R., Stark, A. W., \& Thomas, H. M. (2000, December). Identifying the sources of gains from takeovers. Accounting Forum, 24(4), 319-343.

Mantravadi, P., \& Reddy, A. V. (2008, January). Post-merger performance of acquiring firms from different industries in India. International Research Journal of Finance \& Economics, 22, 192-204.

Martynova, M., \& Renneboog, L. (2008, October). A century of corporate takeovers: What have we learned and where do we stand? Journal of Banking \& Finance, 32(10), 2148-2177.

Melicher, R. W., \& Rush, D. F. (1974, February). Evidence on the acquisition-related performance of conglomerate firms. The Journal of Finance, 29(1), 141-149.

Mishra, P., \& Chandra, T. (2010). Mergers, acquisitions and firms' performance: Experience of Indian pharmaceutical industry. Eurasian Journal of Business \& Economics, 3(5), 111-126.

Neethu, T. C., Viswanathan, R., \& Arun, T. C. (2018, August). Mergers and acquisitions waves in India. International Journal of Management Studies, 5(4), 17-22.

Parrino, J. D., \& Harris, R. S. (1999, January). Takeovers, management replacement, and post-acquisition operating performance: Some evidence from the 1980s. Journal of Applied Corporate Finance, 11(4), 88-96.

Pawaskar, V. (2001, January). Effect of mergers on corporate performance in India. Vikalpa, 26(1), 19-32.

Rahman, R. A., \& Limmack, R. J. (2004, May). Corporate acquisitions and the operating performance of Malaysian companies. Journal Business Finance \& Accounting, 31(34), 359-400.

Ramakrishnan, K. (2008, April). Long-term post-merger performance of firms in India. Vikalpa, 33(2), 47-63. 
Ramaswamy, K. P., \& Waegelein, J. F. (2003, February). Firm financial performance following mergers. Review of Quantitative Finance \& Accounting, 20(2), 115-126.

Ravenscraft, D. J., \& Scherer, F. M. (1987, February). Life after takeover. The Journal of Industrial Economics, 36(2), 147-156.

Ravenscraft, D. J., \& Scherer, F. M. (1989, February). The profitability of mergers. International Journal of Industrial Organization, 7(1), 101-116.

Reddy, K. S., Nangia, V. K., \& Agrawal, R. (2014, September). The 2007-2008 global financial crisis, and cross-border mergers and acquisitions: A 26-nation exploratory study. Global Journal of Emerging Market Economies, 6(3), 257-281. Doi: 10.1177/0974910114540720

Sharma, D. S., \& Ho, J. (2002, February). The impact of acquisitions on operating performance: Some Australian evidence. Journal of Business Finance \& Accounting, 29(1-2), 155-200.

Switzer, J. A. (1996, December). Evidence on real gains in corporate acquisitions. Journal of Economics \& Business, 48(5), 443-460.

Wan, W. P., \& Yiu, D. W. (2009, July). From crisis to opportunity: Environmental jolt, corporate acquisitions, and firm performance. Strategic Management Journal, 30(7), 791-801.

Zollo, M., \& Singh, H. (2004, December). Deliberate learning in corporate acquisitions: Post- acquisition strategies and integration capability in U.S. bank mergers. Strategic Management Journal, 25(13), 1233-1256. 